九州大学学術情報リポジトリ

Kyushu University Institutional Repository

Feasibility of an East Asian FTA and Common Agricultural Policy: Analysis of Agricultural and Environmental Impacts

Suzuki, Nobuhiro

Department of Global Agricultural Sciences, the University of Tokyo

Kinoshita, Junko

Policy Research Institute, Ministry of Agriculture, Forestry and Fisheries

Kano, Hideyuki

Faculty of Agriculture, Kyushu University

https://doi.org/10.5109/9336

出版情報: 九州大学大学院農学研究院紀要. 52 (2)，pp.451-464，2007-10-29. Faculty of Agriculture, Kyushu University

バージョン：

権利関係 : 


\title{
Feasibility of an East Asian FTA and Common Agricultural Policy: Analysis of Agricultural and Environmental Impacts
}

\author{
Nobuhiro SUZUKI ${ }^{1 *}$, Junko KINOSHITA² and Hideyuki KANO \\ Laboratory of Food Industrial System Analysis, Division of Industrial Organization of Agribusiness, \\ Department of Agricultural and Resource Economics, Faculty of Agriculture, \\ Kyushu University, Fukuoka 812-8581, Japan \\ (Received June 30, 2007 and accepted July 17, 2007)
}

\begin{abstract}
Since the current WTO (World Trade Organization) rules have several unfair aspects favorable to exporting countries with large-scale farms like the U.S. and Australia, it would be impossible for Asian small-scale farming to survive under the rules. The rules are focusing on economic efficiency without considering equitable distribution of wealth and external economies such as national security and environmental concerns. Furthermore, although it is said that a total ban on export subsidies by the end of 2013 was agreed, the pledge is very unlikely to be fulfilled because many "hidden" export subsidies are left out of this agreement. Therefore, forming the East Asian FTA (Free Trade Agreement) is a way to strengthen cooperative relationships against unfairly severe free trade pressure from exporting countries with large-scale farms. It is important to jointly establish new criteria for East Asian food trade to ensure sustainable and diversified agriculture. In the longer term, it could serve as a good model for establishing fair food trade rules under the WTO. However, our analysis showed that the East Asian FTA could endanger existence of Japan and Korea's rice farming because of huge gaps in agricultural prices and costs between Japan/Korea and other East Asian countries. Therefore, we need a measure to adjust the current agricultural productivity gaps in the East Asia. A feasible measure is establishing the East Asian CAP (Common Agricultural Policy) with a fund collected in proportion to the GDP level of each partner country just like the EU budget. Using the funds, the uneven distribution of FTA benefits can be redistributed across borders.
\end{abstract}

\section{INTRODUCTION}

In recent years, the proliferation of regional Free Trade Agreements (FTAs) and Economic Partnership Agreements (EPAs) has become a global trend. Especially, the NAFTA (North American Free Trade Agreement) and the EU (European Union) are further accelerating their course of regional integration, and their successful integration substantiated the great benefits that FTAs generate. Many countries will increasingly accelerate FTA establishment to avoid political and economic isolation in the world. In view of these facts, Asian countries should reaffirm the need for creating their unique FTA.

The U.S. is strongly against the Asian FTA because it will have a great countervailing power in the world. It is unfair because the U.S. already has the NAFTA and then the U.S. is approaching to Asian countries. Asian countries should have a right to form a FTA only by Asian countries to strengthen Asian economic cooperation and generate a countervailing power against the European and American blocs.

Possible member countries of the Asian FTA at the first stage should be "ASEAN plus Three" consists of 10 ASEAN countries, Japan, Korea, and China. Then, it could be gradually expanded to other Asian countries.

\footnotetext{
${ }^{1}$ Department of Global Agricultural Sciences, the University of Tokyo, Japan

${ }^{2}$ Policy Research Institute, Ministry of Agriculture, Forestry and Fisheries, Japan

* Corresponding auther (E-mail: asuzukiz@mail.ecc.u-tokyo. ac.jp)
}

That's because FTA negotiations among few countries are apt to be concluded easily, while including too many countries (for example, including Australia, New Zealand, or all APEC countries) at the first step will make it more time-consuming to reach an agreement.

East Asian countries, or ASEAN plus Three, have diversity in food and agriculture as well as several common characteristics such as small-scale rice farming that are completely different from the U.S. and Australia. Forming the East Asian FTA is a way to strengthen cooperative relationships against unfairly severe free trade pressure from exporting countries with large-scale farms. Therefore, it is important to jointly establish new criteria for East Asian food trade to ensure sustainable and diversified agriculture. In the longer term, it could serve as a good model for establishing fair food trade rules under the WTO (World Trade Organization).

In this paper, we describe why we should now create the East Asian FTA based on analyses on merits/demerits of trade liberalization under FTAs and the WTO. Then, we propose what we should do to successfully establish the East Asian FTA based on a simulation analysis on the feasibility of making an East Asian common agricultural policy and common funds. In the simulation analysis, we consider not only possible food tariff reduction rates and budgetary constraints, but also external economies such as deterioration in food self-sufficiency and environmental loads.

\section{UNFAIR ASPECTS OF THE WTO RULES}

"Efficiency" criteria in favor of export countries

The GATT (General Agreement on Tariffs and 
Trade) was established in order to reduce trade barriers non-discriminatorily to all countries and expand international trade through multilateral negotiations. Then the WTO was established in order to make the GATT a more powerful and comprehensive organization. However, the WTO rules have several aspects of unfairness against Asian countries.

Firstly, the current WTO criteria for reducing agricultural protection are focusing on economic efficiency or maximization of the total economic welfare which is apparently favorable to exporting countries with large-scale farms like the U.S. and Australia. The "efficiency" is narrowly defined without considering equitable distribution of wealth and external economies such as national security and environmental concerns.

The average farm size in Australia is almost 4,000 hectares, over thousand times superior to every Asian country's, while there are not huge gaps in average farm sizes in East Asia. Since Agricultural productivity is severely constrained by the land endowment, it is nearly impossible for most East Asian farmers to compete with the U.S. and Australian farmers with no protection or supports. East Asian countries need new rules more favorable to small-scale farmers in a broader definition with equitable distribution of wealth. Also, in cases where the expansion of international food trade deteriorates environmental loads, we should take them into account when evaluating the costs and benefits of free trade.

\section{Unfairly strict treatment for new members}

Unfairly strict membership conditions tend to be imposed on new WTO members. For example, the membership protocol accepted by Cambodia (joined in 2004) provides that Cambodia shall reduce its average agricultural tariff rate from the current $62.8 \%$ to $29.96 \%$ and the maximum tariff rate from current $100 \%$ to $60 \%$. Table 1 shows average agricultural tariff rates in selected countries. Cambodia's current rate is relatively high, the almost same level as Korea's. The tariff level Cambodia has pledged to attain is below either Thailand's (35\%) or Argentina's (33\%), both major agricultural exporting countries.

In terms of individual commodities, more strict conditions are imposed on Cambodia. Taking the example of dairy products which are the worldwide most sensitive commodities, Canada's butter tariff is 300\% and skimmed milk powder tariff is 200\%, the EU butter tariff is $200 \%$, the U.S. butter is $120 \%$ and skimmed milk powder tariff is $100 \%$, and Thailand's skimmed milk powder tariff is $220 \%$. Moreover, Canada has other commodities with nearly 300\% tariff levels. Since many countries maintain 200-300\% tariffs on sensitive food items, even the U.S. is proposing that a ceiling should be set at $75 \%$ in the WTO Doha negotiations. The 60\% ceiling Cambodia has pledged is extraordinarily low outstripping global norms.

Besides these, Cambodia also pledged to abolish all export subsidies before joining the WTO, or else establish a subsidy reimbursement system by the end of 2013
Table 1. Average Agricultural tariff rates agreed to attain in 2000

\begin{tabular}{lc}
\hline \multicolumn{1}{c}{ Country } & Tariff rate (\%) \\
\hline Norway & 124 \\
India & 124 \\
Korea & 62 \\
Switzerland & 51 \\
Thailand & 35 \\
Argentina & 33 \\
EU & 20 \\
Japan & 12 \\
USA & 6 \\
Canada & 5 \\
Australia & 3 \\
\hline
\end{tabular}

Source: OECD (1999).

(JETRO, 2003). On the other hand, the current world export markets are suspected to be distorted by a huge amount of export subsidies, and many of these won't be eliminated by 2013 as we describe later. This means that Cambodia will be placed under disadvantageous conditions in that Cambodian exports to other countries will be blocked with high barriers while Cambodian import barriers are significantly reduced.

China had to reduce tariffs to very low levels when it joined the WTO. For example, China's dairy tariffs were reduced to the rage of $10-20 \%$ in 2005. This is considerably low compared to the EU, the U.S. and Canada's tariff levels ranging from 200 to $300 \%$. They are shutting out dairy imports from Oceania and exporting many dairy products to China. Consequently, dairy prices declined in China and a share of imports in Chinese domestic dairy demand has increased rapidly.

\section{"Hidden" export subsidies never fully eliminated by 2013}

The current world agricultural markets are suspected to be distorted by a huge amount of direct and indirect export subsidies. It is said that a total ban on export subsidies by the end of 2013 was promised in the Hong Kong agreement of the WTO Doha Round in December 2005, but the pledge is very unlikely to be fulfilled virtually, because many indirect export subsidies are not covered by the current WTO criteria. We refer to such an unregulated subsidy with price-lowering effects on exports as a "hidden export subsidy" in this paper. Let us take the following three examples of hidden export subsidies by major export countries.

The U.S. grain, soybean, and cotton support policies

Firstly, we examine the U.S. domestic supports for rice. The similar support measures are applied to other grain, soybean, cotton etc. They are classified into domestic policies under the current WTO rules, but suspected to be effectively working as export subsidies. Let us explain it with Fig. 1. We apply Japan's rice price levels to the U.S. system for descriptive purposes.

Given that a loan rate is 12,000 yen, a fixed payment is 2,000 yen, a target price is 18,000 yen, and an international price is 4,000 yen per sack of rice $(60 \mathrm{~kg})$, if a farmer pledged a sack of rice to the government 
(Commodity Credit Corporation $=\mathrm{CCC}$ ) for a loan of 12,000 yen and sold the rice at the international price level, the farmer is supposed to repay only its proceeds or 4,000 yen (called a "marketing loan"). In addition, the farmer can receive both a fixed payment and a "countercyclical payment" from the government. The amount of countercyclical payment is 4,000yen, the difference between 18,000yen (target price) and 14,000 yen (loan rate + fixed payment) and therefore increases as market price decreases and vice versa. On the other hand, if a farmer didn't use the loan rate system, the farmer is supposed to receive the difference between 12,000 yen (loan rate) and 4,000 yen (farmer's proceeds) as well as a fixed payment and a countercyclical payment. To put it briefly, regardless of whether or not the loan rate system is used, a farmer can receive 14,000 yen per sack of rice from the government.

Fig. 2 clearly shows how this U.S. system has price-lowering effects on exports. In case of an ordinal export subsidy regulated in the WTO rules, the amount of export subsidy is the area A. When $100 \mathrm{~kg}$ of products are sold at 100 dollars in the domestic market and the other $100 \mathrm{~kg}$ are exported at 50 dollars, the government (i.e., taxpayers) pays the difference between domestic and export prices to farmers or exporters. Thus, farmers' revenue is 20,000 dollars (= 100 dollars $\times 200 \mathrm{~kg}$ ) in this example of an ordinal export subsidy.

In the U.S. system, both domestic and export prices are 50 dollars, and the government pays farmers 50 dollars, the difference between target and market prices, for both of domestic and export sales. The total support amount is the area A + B. Since this support includes the area A, it obviously works as an export subsidy.

Why this system is not classified into the ordinal export subsidy to be eliminated by 2013? That's because the payment is not "export contingent," but for all sales. In the current WTO rules, only the payments targeted to exports are regulated.

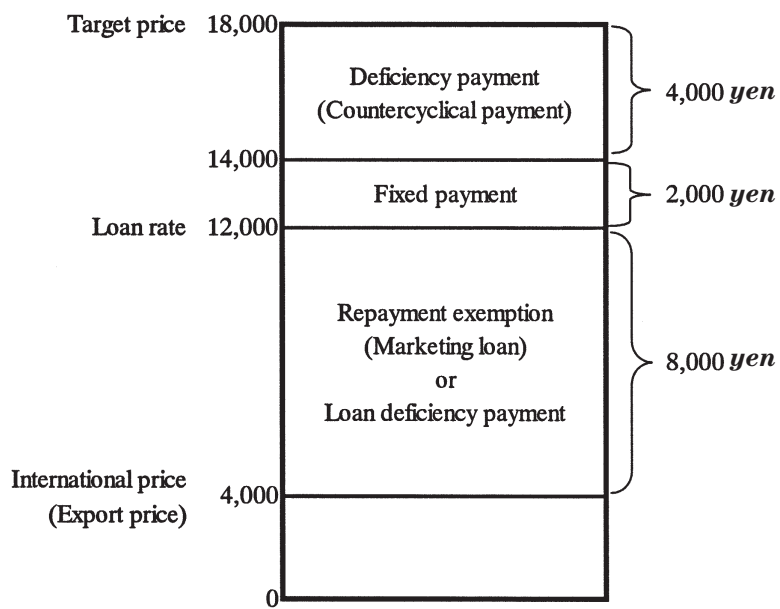

Fig. 1. Illustration of the U.S. subsidies for grain, soybean, and cotton.

Note: Japan's nice price levels $(y e n / 60 \mathrm{~kg}$ ) are employed for descriptive purposes.
Most cheap agricultural exports of the U.S. would not exist without "hidden" export subsidies. Furthermore, the U.S. attempted to modify the WTO rules with the consent of the EU so that these subsidies could be certified as blue box policies which are not subject to reduction for the time being. That is, they insisted that their payments were unrelated to current production (in other words, they were based on past acres regardless of present usage) even these were not accompanied by any supply control measures. In the event, Brazil and many countries were strongly opposed to this allegation and the WTO panel judged that the U.S. measures caused "serious prejudice" to Brazilian exports. Nevertheless, the panel decision has not yet been incorporated into the WTO rule.

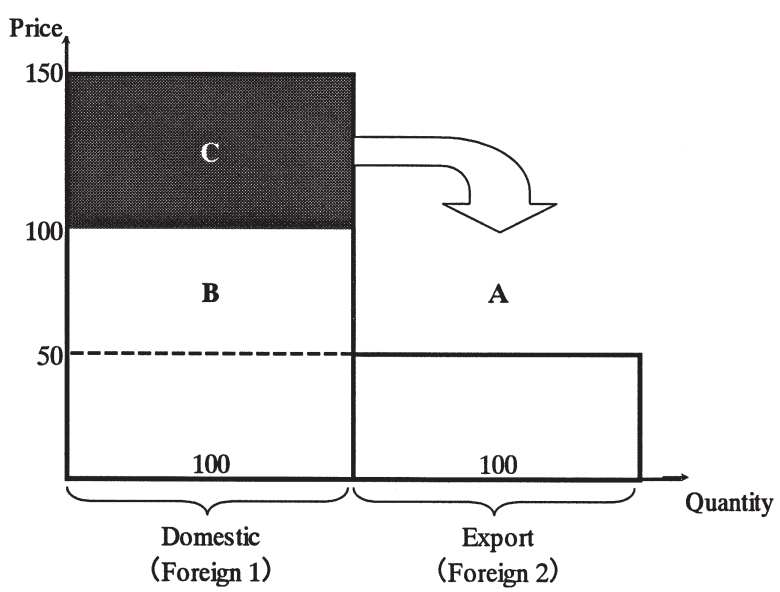

Fig. 2. Types of Export subsidy and equivalents.

Notes: A corresponds to an ordinary export subsidy financed by the government.

$\mathbf{A}+\mathbf{B}$ corresponds to the U.S. direct payment for grain etc. financed by the government.

C corresponds to the Canada, Australia and NZ's price discrimination measures financed by consumers.

Each makes an equal amount of Export subsidy equivalent, 5000, in this case.

\section{Canadian milk pricing system}

Secondly, we examine a Canadian milk pricing system. In this system, the government doesn't pay the area A (Fig. 2), but the monopolistic marketing board raises domestic consumer prices. When Canadian domestic dairy price is set at 150 dollars and export price is 50 dollars, farmers can receive a weighted average of domestic and export prices and their revenue is 20,000 dollars $(=100$ dollars $\times 200 \mathrm{~kg})$. The amount of farmers' revenue is the same as an ordinary export subsidy case, but subsidy payers are different. That is, the area $\mathrm{A}$ is paid by government in an ordinary export subsidy case, while in this Canadian case the area $\mathrm{C}$ is paid by consumers. The WTO panel admitted that the Canadian milk pricing system was an ordinary export subsidy because of its export contingency.

Australia and New Zealand's export state trading

Thirdly, Australia and New Zealand's export state trading systems are also not classified into ordinary export subsidies, though they are highly likely to work 
as export subsidies. Moreover, Australia is asserting that they are never export subsidies while refusing the submission of statistical data required for verification of those trade distortion effects.

The Australian wheat export system is very similar to the Canadian case above. Replace "Domestic" and "Export" on the X-axis in Fig. 2 by "Foreign 1" and "Foreign 2," respectively. The Canadian system was price discrimination between domestic and export markets, while the Australian system is price discrimination among export markets with monopoly power of an export state trading enterprise. For example, when Australia sells its wheat in Japan at 150 dollars and in china at 50 dollars, Australia can get larger total export sales than it would with the same price. That means Japanese consumers are financing lower-price exports to China. New Zealand's dairy export state trading has a similar scheme.

\section{DEMERITS OF FTAS}

\section{History and political significance of the WTO}

Establishing an East Asian FTA might be a good idea, but yet we should not underestimate the political significance of the WTO.

First of all, we should never forget about history of the GATT and the WTO. Before the GATT was established in 1947, there were several regional blocs and each bloc continued enhancing its solidarity. This is recognized as a major cause of the World War II and that's how the GATT was established.

FTAs are approved by the GATT article 24 on condition of liberalizing "substantially all the trade." However, FTAs are essentially inconsistent with the GATT/WTO philosophy, because the GATT/WTO principle regulates non-discriminative and gradual reduction of trade barriers through multilateral negotiations among all members, while the FTA principle regulates discriminative and immediate elimination of trade barriers only among partners. Moreover, in practical terms, since the definition of "substantially all the trade" is ambiguous, it is generally recognized that an eligible FTA should eliminate tariffs and other measures on more than $90 \%$ of its trade value within 10 years, which implies that each FTA can keep exemptions up to $10 \%$.

History is ironical. The WTO negotiations were recently stagnant and many countries around the world are getting committed to regional blocs again. We should keep in mind that increasing FTAs might generate a dangerous situation in the future.

\section{FTAs increase world market imperfect competi- tiveness}

Krugman (1991)'s analysis showed that it would be the worst case for the world economic welfare when there are three regional blocs, which is suggestive of the future world consists of European, American and Asian blocs. This consequence, however, is fragile because the analysis has an assumption that each bloc can set optimal tariffs although practically a FTA or a CU (Customs
Union) member is prohibited from raising tariff rates on imports from non-partner countries by the GATT article 24.

On the other hand, Suzuki (2005)'s analysis showed that the world economic welfare would decrease even under a zero-tariff assumption. That's because the degree of imperfect competitiveness of the world market would increase as seen below.

Assume that there are two blocs in the world. Each bloc has one Cournot firm (or an alliance to maximize their joint profits) that produces one homogenous product taking another bloc's supply as given. They trade with no transportation costs and no resale of products. Each bloc's supply and demand functions are:

Bloc 1's demand function $\quad D_{1}=1530-17 P_{1}$,

Bloc 1's (inverse) marginal cost function

$$
\begin{array}{ll} 
& S_{1}=155+33 M C_{1}, \\
\text { Bloc 2's demand function } & D_{2}=850-20 P_{2},
\end{array}
$$

Bloc 2's (inverse) marginal cost function

$$
\begin{aligned}
& D_{1}=X_{11}+X_{21}, \\
& D_{2}=X_{12}+X_{22}, \\
& S_{1}=X_{11}+X_{12} \\
& S_{2}=X_{21}+X_{22}
\end{aligned}
$$

$$
S_{2}=25+40 M C_{2}
$$

where $D$ is quantity demanded $(10,000$ ton $), P$ is price (10,000 yen/ton), $S$ is quantity supplied (10,000 ton), and $X_{i j}$ is quantity supplied from bloc $i$ to $j$ (10,000 ton). Under these assumptions, the optimal conditions are:

$$
\begin{aligned}
& M R_{11}=M R_{12}=M C_{1} \text { for bloc } 1, \\
& M R_{21}=M R_{22}=M C_{2} \text { for bloc } 2,
\end{aligned}
$$

where $M R_{i j}$ is bloc $i$ 's "perceived" marginal revenue in market $j$. These conditions are expressed as:

$$
\begin{aligned}
90-\left(2 X_{11}+X_{21}\right) / 17 & =42.5-\left(2 X_{12}+X_{22}\right) / 20 \\
& =\left(X_{11}+X_{12}-155\right) / 33, \\
90-\left(X_{11}+2 X_{21}\right) / 17 & =42.5-\left(X_{12}+2 X_{22}\right) / 20 \\
& =\left(X_{21}+X_{22}-25\right) / 40 .
\end{aligned}
$$

Solving the above simultaneous equations, we get equilibrium conditions as:

$$
\begin{aligned}
& X_{11}=431.9, \\
& X_{12}=191.4, \\
& X_{21}=425.1, \\
& X_{22}=183.4, \\
& P_{1}=39.6, \\
& P_{2}=23.8, \\
& M R_{11}=M R_{12}=M C_{1}=14.2, \\
& M R_{21}=M R_{22}=M C_{2}=14.6 .
\end{aligned}
$$

In this case, there are reciprocal trades with dumping $\left(P_{1}>P_{2}\right)$. Usually, without trade barriers, reciprocal trades of a homogeneous product with discriminated prices would be strange phenomena, but this situation is stable for Cournot players because their "perceived" marginal revenues in both markets are equal to their marginal costs. In this case, it is apparent that the world economic welfare is lower than in a perfectly competitive case.

\section{Major countries' trade liberalization raises world prices}

Agricultural trade is highly protective around the world. It seems that import tariffs and export subsidies 


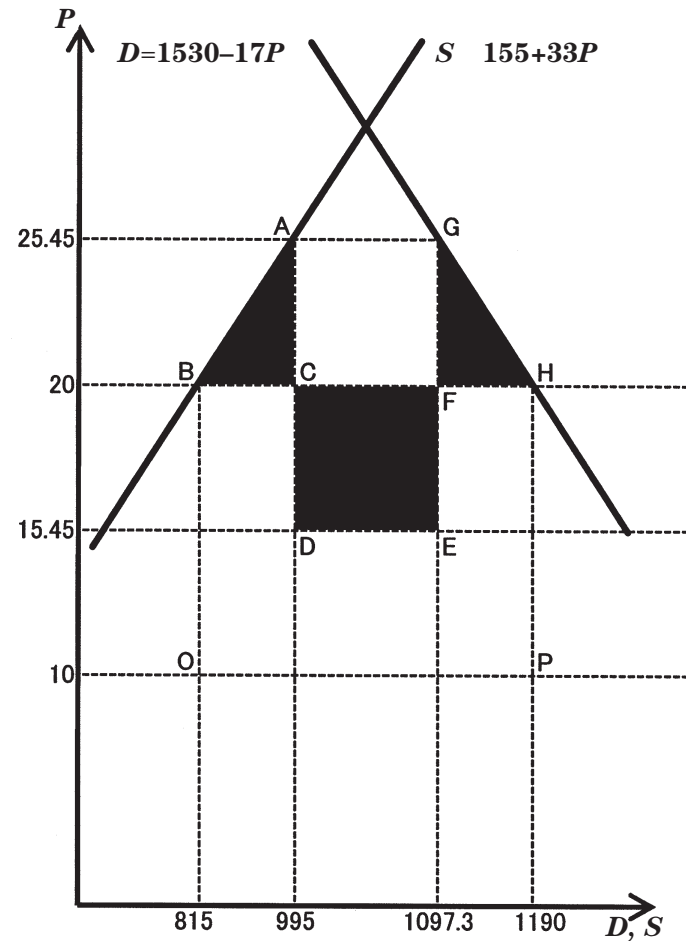

Japan

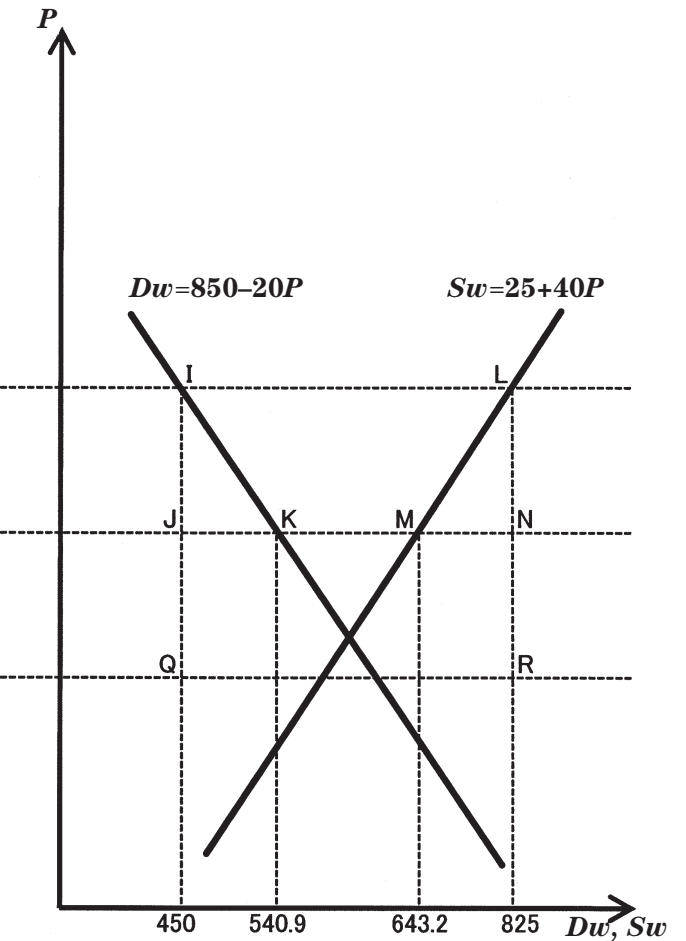

U.S.

Fig. 3. Trade liberalization could decrease economic welfare.

are distorting world food prices to be considerably low. Therefore, if major countries eliminate their tariffs and subsidies, the relevant world prices will rise steeply. See the following example.

Assume that the world is consists of two countries, Japan and the U.S., rice is the only product produced and traded, and transportation costs are negligible. We use the same supply and demand functions in the preceding chapter replacing Bloc 1 and 2 into Japan and the U.S., respectively.

See Fig. 3. When there is no protection at all, both international and domestic prices are $20(\mathrm{BH}=\mathrm{IL})$. When Japan imposes 10 per unit of imports as a specific tariff, the U.S. domestic and export prices are both 15.45 and the Japan's domestic price is $25.45(\mathrm{KM}=\mathrm{DE}=\mathrm{AG})$. In this case, eliminating the tariffs improve Japan's economic welfare by 27.9 billion yen because a consumer surplus increment net of producer losses ( $\mathrm{ABHG}$ ) is larger than a tariff revenue loss (ADEG). (ABC + GFH$\mathrm{CDEF}=74.38-46.49)$. However, when Japan imposes 10 per unit of imports as a specific tariff and the U.S. pays 10 per ton as an export subsidy, the U.S. domestic price is 20 while export price is 10, and Japan's import price is 10 while domestic price is 20 ( $\mathrm{IL}=\mathrm{QR}=\mathrm{OP}=$ $\mathrm{BH})$. Eliminating both tariffs and subsidies results in no changes in both countries' domestic prices. That is, Japanese consumers will not gain, while Japan will suffer losses of 375 billion yen in tariff revenues $(\mathrm{BOPH}=$ IQRL). On the other hand, the world total economic welfare remains unchanged in this case.

\section{Who will suffer from trade diversion effects?}

Another well-known problem associated with FTAs is a trade diversion effect. For example, if Japan eliminates a pork tariff under a Japan-Mexico FTA, Mexico will gain while other pork exporting countries like Denmark and the U.S. will suffer losses. Japan will gain if the amount of Japanese consumers' benefits (net of producers' losses) due to lower price exceeds lost tariff revenues. Alternatively, Japan will suffer losses if consumers' benefits (net of producers' losses) fall below lost tariff revenues. Regarding the world total economic welfare, it is uncertain whether it will be improved through trade diversion.

Kawasaki run a simulation analysis (Suzuki, 2005) using a GTAP model (a standard Computable General Equilibrium model for international trade) on selected countries' gains and losses from Thailand-Japan and Korea-Japan FTAs. As shown in Table 2, the results indicated that almost all non-partner countries will suffer losses assuming Japan's agricultural tariffs are eliminated.

Interestingly, if Japan's sensitive agricultural products are excluded from each FTA, Japan's gains will increase. This finding implies that lost tariff revenues exceed consumers' benefits (net of producers' losses) if high tariffs on sensitive products are eliminated. These losses are partly caused by trade diversion effects and a rise in the international price induced by substantial increases in imports into Japan.

Moreover, if Japan's sensitive products are excluded, Thailand and Korea's gains will decrease, while most 
Table 2. Simulation results on gains and losses relating Japan-Thailand and Japan-Korea FTAs (Million US\$)

\begin{tabular}{|c|c|c|c|c|}
\hline \multirow[b]{2}{*}{ Country } & \multicolumn{2}{|c|}{ Japan-Thailand FTA } & \multicolumn{2}{|c|}{ Japan-Korea FTA } \\
\hline & No Exception & $\begin{array}{l}\text { Sensitive Products } \\
\text { Exception }\end{array}$ & No Exception & $\begin{array}{l}\text { Sensitive Products } \\
\text { Exception }\end{array}$ \\
\hline Japan & 373 & 1,034 & 750 & 1,260 \\
\hline Thailand & 2,493 & 1,213 & -113 & -105 \\
\hline Korea & -232 & -189 & 2,021 & 1,578 \\
\hline China & -334 & -231 & -306 & -278 \\
\hline Hong Kong & -96 & -51 & -12 & -7 \\
\hline Taiwan & -216 & -194 & -112 & -106 \\
\hline Indonesia & -99 & -75 & -76 & -69 \\
\hline Malaysia & -175 & -140 & -77 & -76 \\
\hline Philippines & -51 & -47 & -30 & -29 \\
\hline Singapore & -234 & -196 & -52 & -53 \\
\hline Vietnam & -10 & -17 & -18 & -16 \\
\hline Oceania & -49 & -70 & -130 & -119 \\
\hline South Asia & -50 & -37 & -18 & -15 \\
\hline Canada & -9 & 13 & -13 & -6 \\
\hline U.S. & -643 & -528 & -588 & -575 \\
\hline Mexico & 0 & 11 & 11 & 15 \\
\hline Latin America & -27 & -58 & -127 & -115 \\
\hline Europe & -681 & -446 & -287 & -270 \\
\hline Others & -116 & -131 & -338 & -323 \\
\hline
\end{tabular}

Source: Analysis by K. Kawasaki with GTAP model (a standard Computable General Equilibrium model for international trade), Chapter 9 in Suzuki (2005).

Note: Sensitive products include rice, sugar and poultry in Japan-Thailand FTA; rice, pork, milk and milk products in Japan-Korea FTA. Starch is not included due to lack of data.

Economic welfare is measured by equivalent variation, which is an indicator of the degree of economic satisfaction expressed by dollars.

non-partner countries' losses will decrease. This is partly caused by reduced trade diversion effects due to maintaining high tariffs on sensitive products. Since tariff levels and other supports for sensitive products are currently very high, eliminating them only for partners would maximize negative effects on non-partner countries. Accordingly, a way of minimizing these negative effects on the rest of the world would be to exclude sensitive products.

It is generally recognized that an eligible FTA should eliminate tariffs and other measures on more than $90 \%$ of its trade value within 10 years, which implies that each FTA can keep exemptions up to $10 \%$. It is not so difficult for Japan to clear the "90\% rule." Japan currently has several high-tariff items including rice (about $490 \%)$, butter (330\%), milk powder (200\%), etc., but the number of such items is limited and tariffs on the other items are rather low. Therefore, if Japan eliminates already low level tariffs on most items, it should be permissible to keep high tariffs on several sensitive items. However, in case of the Asian FTA, it won't be practically easy to entirely exclude Japan's rice because rice exports are very crucial for most Asian countries.

\section{NEEDS AND FEASIBILITY OF THE EAST ASIAN FTA}

\section{Is an East Asian FTA better than the WTO?}

We employ a simple simulation analysis to compare possible impacts of trade liberalization under FTAs and the WTO. For simplicity, we assume that the world is composed of only four countries: Japan, Korea, China and the U.S., and each country is producing and trading the only homogeneous product, rice. We analyze on three cases: Japan-Korea FTA, Japan-Korea-China FTA, and free trade among all four countries. These three cases comparatively correspond to a bilateral FTA, an East Asian FTA, and the global free trade under the WTO, respectively. The data of current prices, quantities supplied and demanded, and exports are shown in Table 3. Using these data, we calculated liner demand and supply functions. Slopes and intercepts of each function are shown in Table 3.

We also examined external effects including changes in nitrogen load, food miles, and virtual water. In Japan, population density is so high that the amount of nitrogen released into the environment is already excessive. According to a report released in 2004 by Japan's National Institute for Agro-Environmental Services (in Japanese), the maximum nitrogen level which Japan's farm land can circulate properly (the total farm land nitrogen capacity) is about 1,237 thousand tons $(250 \mathrm{~kg} / \mathrm{ha})$, while the domestic food-derived nitrogen supply is 2,379 thousand tons in 1997 . The ratio of food-derived nitrogen supply to total farm land capacity is already $192 \%$.

For our simulation analysis, the total nitrogen capacity in domestic farm land (Nmax) is calculated by:

$N \max =1237.3-(888.9-S) / 532 \times 250$, where $S$ is Japan's annual rice production (888.9 thou- 
Table 3. Data for rice supply, demand, and food miles

\begin{tabular}{|c|c|c|c|c|c|}
\hline & \multicolumn{5}{|c|}{ Liner Supply Functions (in million tons, yen/kg) } \\
\hline & Supply & $\begin{array}{c}\text { Price } \\
\text { Elasticity }\end{array}$ & Price & Slope & Intercept \\
\hline Japan & 8.889 & 1.173 & 269.300 & 3.870 & -153.800 \\
\hline Korea & 6.687 & 0.350 & 193.400 & 1.210 & 434.700 \\
\hline China & 176.340 & 0.200 & 36.200 & 97.430 & 14107.200 \\
\hline \multirow[t]{3}{*}{ U.S. } & 10.470 & 0.200 & 36.200 & 5.780 & 837.600 \\
\hline & \multicolumn{5}{|c|}{ Exports (in thousand tons) } \\
\hline & To Japan & To Korea & To China & To U.S. & Total \\
\hline Japan & - & 0.000 & -106.000 & -318.000 & -424.000 \\
\hline Korea & 0.000 & - & -74.000 & 0.000 & -74.000 \\
\hline China & 106.000 & 74.000 & - & 0.000 & 180.000 \\
\hline \multirow[t]{3}{*}{ U.S. } & 318.000 & 0.000 & 0.000 & - & 318.000 \\
\hline & \multicolumn{5}{|c|}{ Liner Demand Functions (in million tons, yen/kg) } \\
\hline & Demand & $\begin{array}{c}\text { Price } \\
\text { Elasticity }\end{array}$ & Price & Slope & Intercept \\
\hline Japan & 9.313 & -0.010 & 269.300 & -0.035 & 940.600 \\
\hline Korea & 6.761 & -0.200 & 193.400 & -0.699 & 811.300 \\
\hline China & 176.160 & -0.120 & 36.200 & -58.400 & 19729.900 \\
\hline \multirow[t]{3}{*}{ U.S. } & 10.152 & -0.280 & 36.200 & -7.850 & 1299.500 \\
\hline & \multicolumn{5}{|c|}{ Distance Parameters for Food Miles } \\
\hline & Japan & Korea & China & U.S. & \\
\hline Japan & 0.000 & 1.953 & 3.006 & 13.053 & \\
\hline Korea & 1.953 & 0.000 & 1.371 & 14.097 & \\
\hline China & 3.006 & 1.371 & 0.000 & 15.483 & \\
\hline U.S. & 13.053 & 14.097 & 15.483 & 0.000 & \\
\hline
\end{tabular}

Source: Hokazono (2006), Maeda and Kano (2005) and Suzuki (2006).

Note: The U.S. rice price, a yen equivalent of the target price under the 2002 Farm Bill, was almost the same as China's.

sand tons in 2002). A decrease in rice production $(888.9-S)$ is divided by an average rice yield $(532 \mathrm{~kg} / 10 \mathrm{a}$ in 2002) to get a decrease in farm land, and then it is multiplied by the per unit domestic farm land nitrogen capacity $(250 \mathrm{~kg} / \mathrm{ha}$ ) to get the value of $N$ max. It is assumed that the diminished farm land is transformed into urban land and the urban land nitrogen capacity is zero. Domestic supply of food-derived nitrogen $(N)$ is calculated by:

$$
\begin{aligned}
N= & 2379+(\mathrm{D}-931.3) \times 0.0683 \times 0.168 \times 10^{-} \\
& (888.9-S) / 532 \times 110,
\end{aligned}
$$

where $D$ is Japan's annual rice demand for direct consumption (931.3 thousand tons in 2002). A rice demand increment $(D-931.3)$ is multiplied by protein content of rice $(6.83 \%)$ and the nitrogen-to-protein conversion factor (16.8\%) (Shindo et al., 2003) to get the total food-derived nitrogen supply, and then a decrease in fertilizer-derived nitrogen supply is subtracted to get the value of $N$. Nitrogen fertilizer input of rice farming is $110 \mathrm{~kg} / \mathrm{ha}$ according to a report by Japan's Ministry of Agriculture. The ratio of food-derived nitrogen supply to total farm land capacity is defined by N/Nmax.

The definition of food miles is: imports (ton) multiplied by transportation distance $(\mathrm{km})$. This is an indicator of environmental load of energy consumption associ- ated with food trade.

Virtual water is an indicator of changes in water demand/supply balance associated with substitution between domestic production and import of food. Oki et al. (2003) estimated that we need additionally $3,600 \mathrm{~m}^{3}$ of water per ton per year if imported rice is replaced by domestic production in Japan.

The simulation results regarding market impacts, economic welfare, and environmental indicators are shown in Table 4, 5 and 6, respectively.

The results about market impacts (Table 4) showed that rice price significantly decrease except in the Japan-Korea FTA. In this analysis, these impacts can be somewhat overestimated with assumptions on Japan's highly elastic rice supply and perfect substitution between domestic and imported rice consumption. Nevertheless, the results sufficiently represent that the East Asian FTA and the WTO cases could have destructive impacts on Japan's rice production.

Japan's self-sufficiency rates of rice decline to unacceptable levels, 1.4 and 1.7\%, in the East Asian FTA and the WTO cases, respectively.

The results about economic welfare (Table 5) showed that Japan will not gain in the Japan-Korea FTA. That's because rice price decrease only slightly while 
Table 4. Estimated impacts of WTO and FTAs on rice markets: Supply, demand, and prices

\begin{tabular}{|c|c|c|c|c|c|c|}
\hline & Variables & Unit & Actual & $\begin{array}{c}\text { Japan-Korea } \\
\text { FTA }\end{array}$ & $\begin{array}{c}\text { Japan-Korea- } \\
\text { China FTA }\end{array}$ & WTO \\
\hline \multirow{8}{*}{ Japan } & Supply & $1,000 t$ & 8,889 & 8,256 & 161 & 131 \\
\hline & Demand & $1,000 t$ & 9,313 & 9,319 & 9,391 & 9,391 \\
\hline & Self-sufficiency rate & $\%$ & 95 & 89 & 2 & 1 \\
\hline & Market price & yen/kg & 269 & 253 & 44 & 43 \\
\hline & Imports from China & $1,000 t$ & 106 & 0 & 9,230 & 9,260 \\
\hline & Imports from the U.S. & $1,000 t$ & 318 & 0 & 0 & 0 \\
\hline & Imports from Korea & $1,000 t$ & 0 & 1,063 & 0 & 0 \\
\hline & Total imports & $1,000 t$ & 424 & 1,063 & 9,230 & 9,260 \\
\hline \multirow{8}{*}{ Korea } & Supply & $1,000 t$ & 6,687 & 7,408 & 4,878 & 4,868 \\
\hline & Demand & $1,000 t$ & 6,761 & 6,345 & 7,806 & 7,812 \\
\hline & Self-sufficiency rate & $\%$ & 99 & 117 & 63 & 62 \\
\hline & Market price & yen/kg & 193 & 253 & 44 & 43 \\
\hline & Imports from China & $1,000 t$ & 74 & 0 & 2,929 & 1,684 \\
\hline & Imports from the U.S. & $1,000 t$ & 0 & 0 & 0 & 1,260 \\
\hline & Total imports & $1,000 t$ & 74 & 0 & 2,929 & 2,944 \\
\hline & Exports to Japan & $1,000 t$ & 0 & 1,063 & 0 & 0 \\
\hline \multirow{7}{*}{ China } & Supply & $1,000 t$ & 176,340 & 176,227 & 183,829 & 183,070 \\
\hline & Demand & $1,000 t$ & 176,160 & 176,227 & 171,671 & 172,126 \\
\hline & Self-sufficiency rate & $\%$ & 100 & 100 & 107 & 106 \\
\hline & Market price & yen/kg & 36 & 36 & 44 & 43 \\
\hline & Exports to Japan & $1,000 t$ & 106 & 0 & 9,230 & 9,260 \\
\hline & Exports to Korea & $1,000 t$ & 74 & 0 & 2,929 & 1,684 \\
\hline & Total exports & $1,000 t$ & 180 & 0 & 12,158 & 10,944 \\
\hline \multirow{7}{*}{ U.S. } & Supply & $1,000 t$ & 10,470 & 10,335 & 10,335 & 10,870 \\
\hline & Demand & $1,000 t$ & 10,152 & 10,335 & 10,335 & 9,610 \\
\hline & Self-sufficiency rate & $\%$ & 103 & 100 & 100 & 113 \\
\hline & Market price & yen/kg & 36 & 34 & 34 & 43 \\
\hline & Exports to Japan & $1,000 t$ & 318 & 0 & 0 & 0 \\
\hline & Exports to Korea & $1,000 t$ & 0 & 0 & 0 & 1,260 \\
\hline & Total exports & $1,000 t$ & 318 & 0 & 0 & 1,260 \\
\hline
\end{tabular}

Table 5. Estimated impacts of WTO and FTAs on rice markets: Changes in economic welfare (billion yen)

\begin{tabular}{|c|c|c|c|c|}
\hline & Variables & $\begin{array}{c}\text { Japan-Korea } \\
\text { FTA }\end{array}$ & $\begin{array}{l}\text { Japan-Korea } \\
\text {-China FTA }\end{array}$ & WTO \\
\hline \multirow{4}{*}{ Japan } & Consumer surplus & 152.36 & 2108.06 & 2115.38 \\
\hline & Producer surplus & -140.20 & -1020.04 & -1020.16 \\
\hline & Government revenue & -98.83 & -98.83 & -98.83 \\
\hline & Total surplus & -86.67 & 989.18 & 996.39 \\
\hline \multirow{4}{*}{ Korea } & Consumer surplus & -390.19 & 1089.00 & 1095.09 \\
\hline & Producer surplus & 419.63 & -864.53 & -868.33 \\
\hline & Government revenue & -11.63 & -11.63 & -11.63 \\
\hline & Total surplus & 17.81 & 212.84 & 215.13 \\
\hline \multirow{4}{*}{ China } & Consumer surplus & 20.35 & -1336.92 & -1202.92 \\
\hline & Producer surplus & -20.36 & 1384.34 & 1241.34 \\
\hline & Government revenue & 0.00 & 0.00 & 0.00 \\
\hline & Total surplus & -0.01 & 47.42 & 38.42 \\
\hline \multirow{4}{*}{ U.S. } & Consumer surplus & 23.89 & 23.89 & -68.25 \\
\hline & Producer surplus & -24.26 & -24.26 & 73.70 \\
\hline & Government revenue & 0.00 & 0.00 & 0.00 \\
\hline & Total surplus & -0.37 & -0.37 & 5.45 \\
\hline
\end{tabular}


Table 6. Estimated impacts of WTO and FTAs on rice markets: Environmental indicators

\begin{tabular}{|c|c|c|c|c|c|c|}
\hline & Variables & Unit & Actual & $\begin{array}{c}\text { Japan-Korea } \\
\text { FTA }\end{array}$ & $\begin{array}{c}\text { Japan-Korea } \\
\text {-China FTA }\end{array}$ & WTO \\
\hline \multirow{4}{*}{ Japan } & Virtual water & $\mathrm{km}^{3}$ & 1.5 & 3.8 & 33.2 & 33.3 \\
\hline & Total nitrogen capacity in farm land (A) & $1,000 t$ & 1237.3 & 1207.5 & 827.2 & 825.8 \\
\hline & Domestic food-derived nitrogen supply (B) & $1,000 t$ & 2379.0 & 2366.0 & 2199.4 & 2198.8 \\
\hline & $\mathrm{B} / \mathrm{A}$ & $\%$ & 192.3 & 195.9 & 265.9 & 266.3 \\
\hline World & Food miles & points & 457.1 & 207.6 & 3175.9 & 4790.6 \\
\hline
\end{tabular}

lost tariff revenues from China and the U.S. are larger. On the other hand, in the other two cases, Japan will gain nearly one trillion yen because free trade with China and the U.S. will hugely decrease rice price and increase consumer surplus. Interestingly, in these two cases, China and the U.S.'s gains derived from increases in exports are considerably small. That's because each country's consumer surplus shrinks due to increased rice price.

The results about environmental loads (Table 6) showed that the $N / N \max$ ratio, currently $192 \%$, would increase to almost 266\% either under the East Asian FTA or under the WTO. That's because farm land capacity sharply reduced by a decrease in domestic paddy fields but fertilizer-derived nitrogen supply decreased less.

The results of food miles showed that trade liberalization under the WTO would be the most energy-consuming regarding transportation, more than ten times the current food mile level. The East Asian FTA would also considerably increase food miles, about seven times the current level.

About $33 \mathrm{~km}^{3}$ of virtual water trade, more than twenty times the current revel, would be generated either with the East Asian FTA or with the WTO cases. Increases in virtual water trade might cause water shortage in exporting countries.

As described above, our simulation results indicated that both the East Asian FTA and global free trade could similarly increase Japan's economic welfare, bur severely increase environmental loads. Another point is that simulation results of the East Asian FTA and the WTO cases are very similar. The East Asian FTA will generate severe damage to Japanese and Korean agriculture because there are currently huge gaps in production costs between Japan/Korea and China.

\section{Huge economic gaps hinder FTAs}

Currently, there are huge gaps in agricultural prices and production costs among East Asian countries. Firstly, we examine price gaps between Japan and Thailand regarding four focal agricultural products. They are considerably huge as follows.

Rice prices in Thailand and Japan are $28 \mathrm{yen} / \mathrm{kg}$ (polished long grain) and 271 yen/kg (unpolished short grain), respectively. Japan's rice tariff rate is about 490\%. Chicken meat prices in Thailand and Japan are $237 \mathrm{yen} / \mathrm{kg}$ (frozen boneless leg) and $650 \mathrm{yen} / \mathrm{kg}$ (chilled leg), respectively. Japan's chicken meat tariff rate is $11.9 \%$. Starch prices are 23 yen $/ \mathrm{kg}$ (tapioca) in Thailand, while $108 \mathrm{yen} / \mathrm{kg}$ (potato) and $139 \mathrm{yen} / \mathrm{kg}$ (sweet potato) in Japan. Japan's starch tariff rates are 25\% (in-quota) and 119 yen/kg (over-quota). Sugar prices are $29 y e n / k g$ (raw cane) in Thailand and 263 yen/kg (raw cane) in Japan. Japan's raw sugar tariff rate is 71.8 yen $/ \mathrm{kg}$.

Next, we examine gaps between Japan and Korea. It is often said that agricultural prices and productivity gaps with Korea are smaller than any other East Asian countries. That can be true according to data shown in Table 7. As for selected 41 items, the weighted average retail price in Seoul is 9\% higher than Fukuoka, while the average price of basic 29 items is $5 \%$ lower in Seoul. For 12 Japanese-type items, the average price is $31 \%$ higher in Seoul. Regarding individual items, for example, Seoul's drinking milk price is only $52 \%$ of Fukuoka, while Seoul's green tea price is $29 \%$ higher than Fukuoka.

However, there are huge gaps in production costs. See Tables 8 and 9 . Korean vegetable production costs are 50\% lower than Japan. Usually, fertilizer, seed, pesticide, and machine costs in Korea are 30\% lower than Japan. Korea's milk production costs are about $60 \%$ of the Japan's levels. Feed and (unpaid) family labor costs are the major sources of these gaps. It is strange that retail prices are almost the same on average though there are huge gaps in production costs. This can be partly explained by larger marketing margins in Korea.

Suzuki (2005) estimated the effects of tariff elimination in the Korean-Japan FTA using a simultaneous equation model. The model was built for estimating impacts on Korea and Kyushu raw milk markets. The current milk price farmers receive is $60 \mathrm{yen} / \mathrm{kg}$ in Korea. When Japan's tariff (21.3\%) is eliminated, Korea can receive $90 \mathrm{yen} / \mathrm{kg}$ if they sell fluid milk in Kyushu (mainly in Fukuoka). The transportation cost between Pusan and Fukuoka is assumed to be $10 \mathrm{yen} / \mathrm{kg}$. Therefore, Korea has incentives to sell raw milk in Fukuoka. The simulation results in Table 10 show that the impacts of milk tariff elimination between Korea and Japan could be significant. Milk imports from Korea will be 214 thousand ton, Kyushu milk price will decrease from 86.3 to 72.3 yen/kg (16\% decrease), Korean milk price will rise from 60 to 62.3 yen $/ \mathrm{kg}$ (3.8\% rise), Kyushu milk production will decrease from 877 to 618 thousand ton (30\% decrease), and Korean milk production will increase from 2,340 to 2,418 thousand ton (3.3\% increase) in a few years. 
Table 7. Retail Food Prices in Fukuoka (Dec.2001) and Seoul (March, 2002)

(Common 29 Items)

\begin{tabular}{|c|c|c|c|c|c|c|c|c|c|c|c|}
\hline \multirow{2}{*}{ Item } & \multirow{2}{*}{ Unit } & \multirow{2}{*}{$\begin{array}{l}\text { Fukuoka } \\
\text { Price Yen }\end{array}$} & \multirow{2}{*}{$\begin{array}{c}\text { CPI } \\
\text { Weight }\end{array}$} & \multicolumn{4}{|c|}{ Seoul Price in Yen ${ }^{1}$} & \multicolumn{4}{|c|}{ Ratio (Fukuoka = 100) } \\
\hline & & & & $\mathrm{DPS}^{2}$ & $\mathrm{SPT}^{3}$ & $\mathrm{CVS}^{4}$ & Average & DPS & $\mathrm{SPT}$ & CVS & Average \\
\hline White Bread & $\mathrm{l} k g$ & 391 & 45 & 625 & 375 & 375 & 458 & 160 & 96 & 96 & 117 \\
\hline Spaghetti & $300 g$ & 137 & 3 & 90 & - & - & 90 & 66 & - & - & 66 \\
\hline Salmon & $100 \mathrm{~g}$ & 201 & 14 & 230 & 200 & - & 215 & 114 & 100 & - & 107 \\
\hline Codfish & $100 g$ & 196 & 0 & 250 & - & - & 250 & 128 & - & - & 128 \\
\hline Prawns & $100 g$ & 273 & 20 & 364 & - & - & 364 & 133 & - & - & 133 \\
\hline Canned Tuna & $80 g$ & 159 & 0 & 75 & 64 & 91 & 77 & 47 & 40 & 57 & 48 \\
\hline Beef Rib-Loin & $100 g$ & 651 & 24 & 750 & 468 & - & 609 & 115 & 72 & - & 94 \\
\hline Pork Shoulder & $100 g$ & 154 & 18 & 120 & 129 & - & 125 & 78 & 84 & - & 81 \\
\hline Chicken & $100 g$ & 111 & 24 & 85 & 69 & - & 77 & 77 & 62 & - & 69 \\
\hline Ham & $100 g$ & 224 & 18 & 180 & 168 & - & 174 & 80 & 75 & - & 78 \\
\hline Whole Milk & $1000 \mathrm{ml}$ & 196 & 46 & 78 & 90 & 135 & 101 & 40 & 46 & 69 & 52 \\
\hline Hen Egg & $1 \mathrm{~kg}$ & 332 & 19 & 450 & 150 & 367 & 322 & 136 & 45 & 111 & 97 \\
\hline Cabbage & $1 \mathrm{~kg}$ & 99 & 7 & 192 & 133 & - & 163 & 194 & 134 & - & 165 \\
\hline Spinach & $1 \mathrm{~kg}$ & 494 & 13 & 500 & 556 & - & 528 & 101 & 113 & - & 107 \\
\hline Lettuce & $\mathrm{l} k \mathrm{~g}$ & 211 & 7 & 967 & 660 & - & 814 & 458 & 313 & - & 386 \\
\hline White Potato & $1 \mathrm{~kg}$ & 215 & 8 & 250 & 218 & - & 234 & 116 & 101 & - & 109 \\
\hline Carrot & $1 \mathrm{~kg}$ & 239 & 9 & 188 & 180 & - & 184 & 79 & 75 & - & 77 \\
\hline Onion & $\mathrm{lkg}$ & 198 & 8 & 175 & 130 & - & 153 & 88 & 66 & - & 77 \\
\hline Tomato & $\mathrm{lkg}$ & 480 & 9 & 550 & 250 & - & 400 & 115 & 52 & - & 83 \\
\hline Apple & $1 \mathrm{~kg}$ & 501 & 23 & 339 & - & 446 & 393 & 68 & - & 89 & 78 \\
\hline Banana & $1 \mathrm{~kg}$ & 200 & 7 & 230 & 250 & - & 240 & 115 & 125 & - & 120 \\
\hline Canned Pineapple & $340 g$ & 134 & 2 & 102 & - & 160 & 131 & 76 & - & 119 & 98 \\
\hline Sugar & $\mathrm{lkg}$ & 189 & 4 & 90 & 108 & 127 & 108 & 48 & 57 & 67 & 57 \\
\hline Mayonaise & $500 \mathrm{~g}$ & 291 & 8 & 233 & 270 & 230 & 244 & 80 & 93 & 79 & 84 \\
\hline Butter-Cookie & $100 g$ & 139 & 13 & - & 88 & 76 & 82 & - & 63 & 55 & 59 \\
\hline Chocolate & $100 g$ & 128 & 12 & 141 & 141 & 143 & 142 & 110 & 110 & 112 & 111 \\
\hline Potatochips & $100 g$ & 133 & 10 & - & 90 & 125 & 108 & - & 68 & 94 & 81 \\
\hline Black Tea & $25 b a g$ & 297 & 4 & - & 280 & 280 & 280 & - & 94 & 94 & 94 \\
\hline \multirow[t]{2}{*}{ Instant Coffee } & $100 g$ & 816 & 9 & 394 & 397 & 450 & 414 & 48 & 49 & 55 & 51 \\
\hline & & & & & & & & \multicolumn{3}{|c|}{ Average of 29 items } & 95 \\
\hline
\end{tabular}

(Common 29 Items)

\begin{tabular}{|c|c|c|c|c|c|c|c|c|c|c|c|}
\hline \multirow{2}{*}{ Item } & \multirow{2}{*}{ Unit } & \multirow{2}{*}{$\begin{array}{l}\text { Fukuoka } \\
\text { Price Yen }\end{array}$} & \multirow{2}{*}{$\begin{array}{c}\text { CPI } \\
\text { Weight }\end{array}$} & \multicolumn{4}{|c|}{ Seoul Price in Yen } & \multicolumn{4}{|c|}{ Ratio (Fukuoka = 100) } \\
\hline & & & & DPS & $\mathrm{SPT}$ & CVS & Average & DPS & SPT & CVS & Average \\
\hline Rice & $10 \mathrm{~kg}$ & 4189 & 89 & 2925 & 3090 & 3850 & 3288 & 70 & 74 & 92 & 78 \\
\hline Rice Cake & $1 \mathrm{~kg}$ & 732 & 8 & - & 255 & - & 255 & - & 35 & - & 35 \\
\hline Tuna Fish & $100 g$ & 319 & 45 & 500 & 450 & - & 475 & 157 & 141 & - & 149 \\
\hline Cod Roe & $100 \mathrm{~g}$ & 621 & 15 & - & - & - & - & - & - & - & - \\
\hline Chinese Cabbage & $1 \mathrm{~kg}$ & 103 & 10 & 100 & 55 & - & 78 & 97 & 53 & - & 76 \\
\hline Dried Shiitake & $100 g$ & 1043 & 2 & 1667 & - & - & 1667 & 160 & - & - & 160 \\
\hline Dried Laver & 1piece & 282 & 13 & 220 & 200 & - & 210 & 78 & 71 & - & 74 \\
\hline Tofu & $100 g$ & 18 & 37 & 49 & 42 & - & 46 & 272 & 233 & - & 256 \\
\hline Fermented Soybeans & $100 g$ & 75 & 10 & - & - & 167 & 167 & - & - & 223 & 223 \\
\hline Pickled Ume & $100 g$ & 185 & 6 & - & 450 & 230 & 340 & - & 243 & 124 & 184 \\
\hline Soy Sauce & $1000 \mathrm{ml}$ & 265 & 5 & 600 & 395 & 660 & 552 & 226 & 149 & 249 & 208 \\
\hline Miso & $\mathrm{l} k g$ & 432 & 11 & 500 & 472 & 500 & 491 & 116 & 109 & 116 & 114 \\
\hline Green Tea & $100 \mathrm{~g}$ & 529 & 23 & 760 & 716 & 574 & 683 & 144 & 135 & 109 & 129 \\
\hline
\end{tabular}

Source: N. Suzuki made this table by revising the Tokyo-Seoul comparison table in Korean Food Market Survey Report in 2002 by Yoshida, Y., K. Adachi, and Y. Takeda.

Note: ${ }^{1}$ One yen $=10$ won. ${ }^{2}$ DPS $=$ department stores. ${ }^{3}$ SPT $=$ supermarkets. ${ }^{4} \mathrm{CVS}=$ convenience stores.

Fermented soybeans, pickled ume, soy sauce and green tea are imported from Japan. Average of 37 items excluding these four items are 104. 
Table 8. Vegetable Production Costs and Work Hours Comparison

\begin{tabular}{|c|c|c|c|c|c|c|}
\hline \multirow{2}{*}{ Commodity } & \multicolumn{2}{|c|}{ Yield $(k g / 10 a)$} & \multicolumn{2}{|c|}{ Costs (yen/kg) } & \multicolumn{2}{|c|}{ Work Hours $($ hour $/ 10 a)$} \\
\hline & Korea & Japan & Korea & Japan & Korea & Japan \\
\hline Cucumber & $11,702.0$ & $15,965.0$ & 60.3 & 157.3 & 835.0 & $1,414.0$ \\
\hline Cucumber $^{1}$ & & & 53.0 & 120.0 & & \\
\hline Tomato & $7,418.0$ & $11,520.0$ & 70.7 & 145.7 & 744.0 & $1,069.0$ \\
\hline Tomato $^{2}$ & & & 40.1 & 168.8 & & \\
\hline Strawberry & $2,685.0$ & $2,407.0$ & 155.6 & 779.0 & 775.0 & $1,121.0$ \\
\hline
\end{tabular}

Sources: http://www.gifu-u.ac.jp/ fukui/03-010622-7.htm

Note: ${ }^{1}$ Cucumer : http://www.geocities.jp/dr_otopy/tpcbk_je.htm

${ }^{2}$ Tomato : http://www.geocities.jp/dr_otopy/tpcbk_jh.htm

Table 9. Average milk production costs in Korea, Japan and Hokkaido in 2002 (yen/kg)

\begin{tabular}{|c|c|c|c|c|c|}
\hline \multirow{2}{*}{ Category } & \multirow{2}{*}{ Korea } & \multirow{2}{*}{ Japan } & \multirow{2}{*}{ Hokkaido } & \multicolumn{2}{|c|}{ Gap } \\
\hline & & & & Korea - Japan & Korea - Hokkaido \\
\hline Feed & 25.38 & 31.37 & 27.21 & -5.99 & -1.83 \\
\hline (Concentrate) & 14.26 & 24.43 & 16.00 & -10.16 & -1.74 \\
\hline (Roughage) & 11.12 & 6.94 & 11.21 & 4.17 & -0.10 \\
\hline Livestock depreciation & 4.56 & 9.55 & 9.31 & -4.99 & -4.75 \\
\hline Building & 1.09 & 1.57 & 1.65 & -0.48 & -0.56 \\
\hline Machinery & 1.93 & 2.65 & 2.37 & -0.72 & -0.44 \\
\hline Labor & 8.15 & 21.11 & 17.74 & -12.96 & -9.59 \\
\hline Sub total & 45.63 & 74.71 & 66.11 & -29.08 & -20.49 \\
\hline By-product & 5.46 & 6.74 & 8.55 & -1.28 & -3.09 \\
\hline Sub total minus By-product & 40.16 & 67.97 & 57.57 & -27.80 & -17.40 \\
\hline Entire cost & 44.50 & 72.87 & 63.99 & -28.37 & -19.49 \\
\hline Milk yield $(\mathrm{kg})$ & $7,070.80$ & $8,834.00$ & $8,836.00$ & & \\
\hline
\end{tabular}

Source: Korean data is from Ms. Kim Jakyung and Japanese data from Ministry of Agriculture.

Table 10. Effects of KJ (Korea-Japan) and KJC (Korea-Japan-China) FTAs on Milk Markets

\begin{tabular}{|c|c|c|c|c|c|c|}
\hline & & Unit & Current & KJFTA & KJCFTA & $\begin{array}{c}\text { KJCFTA } \\
\text { (Domestic } \\
\text { Premium) }\end{array}$ \\
\hline \multirow{11}{*}{ Kyushu } & Milk Production & $1,000 t$ & 877.0 & 618.0 & 175.1 & 533.0 \\
\hline & Fluid Price & yen/kg & 90.1 & 72.3 & 38.2 & 67.1 \\
\hline & Fluid Supply & $1,000 t$ & 690.0 & 618.0 & 175.1 & 533.0 \\
\hline & Fluid Demand & $1,000 t$ & 690.0 & 832.2 & $1,432.0$ & 886.9 \\
\hline & Manufacturing Supply & $1,000 t$ & 187.0 & 0.0 & 0.0 & 0.0 \\
\hline & Manufacturing Price with Subsidies & yen $/ \mathrm{kg}$ & 72.1 & - & - & - \\
\hline & Weighted Average Price & yen/kg & 86.3 & 72.3 & 38.2 & 67.1 \\
\hline & Manufacturing Price & yen/kg & 61.8 & - & - & - \\
\hline & Total Imports & $1,000 t$ & 0.0 & 214.1 & $1,256.9$ & 354.0 \\
\hline & Imports from Korea & $1,000 t$ & 0.0 & 214.1 & 0.0 & 0.0 \\
\hline & Imports from China & $1,000 t$ & 0.0 & 0.0 & $1,256.9$ & 354.0 \\
\hline \multirow{5}{*}{ Korea } & Production & $1,000 t$ & $2,340.0$ & $2,418.3$ & $1,581.4$ & $1,540.3$ \\
\hline & Demand & $1,000 t$ & $2,340.0$ & $2,204.2$ & $4,767.4$ & $5,000.8$ \\
\hline & Price & yen $/ \mathrm{kg}$ & 60.0 & 62.3 & 38.2 & 37.1 \\
\hline & Exports to Kyushu & $1,000 t$ & 0.0 & 214.1 & 0.0 & 0.0 \\
\hline & Imports from China & $1,000 t$ & 0.0 & 0.0 & $3,186.0$ & $3,460.5$ \\
\hline \multirow{6}{*}{ China } & Production & $1,000 t$ & $10,255.0$ & $10,255.0$ & $14,267.0$ & $13,691.3$ \\
\hline & Demand & $1,000 t$ & $10,255.0$ & $10,255.0$ & $9,824.1$ & $9,876.9$ \\
\hline & Price & yen $/ \mathrm{kg}$ & 20.3 & 20.3 & 28.2 & 27.1 \\
\hline & Total Exports & $1,000 t$ & 0.0 & 0.0 & $4,442.9$ & $3,814.5$ \\
\hline & Exports to Kyushu & $1,000 t$ & 0.0 & 0.0 & $1,256.9$ & 354.0 \\
\hline & Exports to Korea & $1,000 t$ & 0.0 & 0.0 & $3,186.0$ & $3,460.5$ \\
\hline
\end{tabular}

Source: Estimates by Suzuki (2005).

Note: Domestic premium is set at 30 yen for Korea and 40 yen for China. 
The results also shows that Korea as well as Japan will be an importer when China joins the FTA because the current milk price is only 20 yen $/ \mathrm{kg}$ in China.

It is highly possible that this simulation overestimated the impacts, because we assumed perfect substitution between domestic and imported milk. That is, Armington elasticity, the degree of substitution between domestic and imported goods, is assumed to be infinity in our model.

An alternative way would be to incorporate a differentiated domestic premium in the model. The premium is a constant price difference remaining unchanged even after trade liberalization, i.e., differentiated domestic premium $=$ domestic price $-($ price in a FTA partner + import tariff + transportation costs + other transaction costs). According to an interview survey by Zushi (2004), Fukuoka consumers would buy Korean and Chinese milk if their retail prices were 94.5 and 72.9 yen per litter, respectively, instead of domestic milk sold at 180 yen per litter. Using this data, we re-simulated
FTA impacts again assuming that domestic premiums are $30 \mathrm{yen} / \mathrm{kg}$ for Korea and $40 \mathrm{yen} / \mathrm{kg}$ for China at the farm gate levels. The results in Table 10 showed that negative impacts on Kyushu dairy farmers would be significantly reduced with the domestic premiums.

In fact, Japanese vegetable farms have been surviving, although production costs in Japan are over twice as higher as in Korea and Japan's import tariffs on vegetables are only $3 \%$ on average. This is an evidence for that Japanese people put substantial premiums on domestic vegetables and it could lessen domestic damages from trade liberalization.

\section{The way to a win-win FTA}

Every country would have both beneficiaries and losers under the East Asian FTA, e.g., Japan would have negative impacts mainly on agricultural sector, while material and parts industries in Korea and motor industries in Malaysia and Thailand would suffer losses. Without any redistribution system of FTA gains, the

Table 11. Estimated impacts of rice tariff elimination in Japan-Korea-China FTA under the East Asian common agricultural policy

\begin{tabular}{|c|c|c|c|}
\hline & Variables & Unit & Estimates \\
\hline \multirow{16}{*}{ Japan } & Supply & $1,000 t$ & $7,808.000$ \\
\hline & Demand & $1,000 t$ & $9,063.000$ \\
\hline & Self-sufficiency rate & $\%$ & 86.200 \\
\hline & Compensation target price of rice & yen/kg & 200.000 \\
\hline & Market price of rice & yen/kg & 126.500 \\
\hline & Imports from China & $1,000 t$ & $1,255.000$ \\
\hline & Tariff rate & $\%$ & 186.424 \\
\hline & Required compensation to Japan & billion yen & 470.800 \\
\hline & $(a)+(b)-(c)$ & & \\
\hline & Supply control (a) & billion yen & 0.000 \\
\hline & Direct payment etc.(b) & billion yen & 574.100 \\
\hline & Tariff revenue (c) & billion yen & 103.300 \\
\hline & Net financial burden on Japan & billion yen & 400.000 \\
\hline & Total nitrogen capacity in domestic arable land (d) & $1,000 \mathrm{t}$ & $1,219.000$ \\
\hline & Food-origin nitrogen released to the environment (e) & $1,000 \mathrm{t}$ & $2,356.000$ \\
\hline & $(\mathrm{e}) /(\mathrm{d})$ & $\%$ & 193.200 \\
\hline \multirow{11}{*}{ Korea } & Supply & $1,000 t$ & $6,118.000$ \\
\hline & Demand & $1,000 t$ & $7,482.000$ \\
\hline & Self-sufficiency rate & $\%$ & 81.800 \\
\hline & Compensation target price of rice & yen/kg & 150.000 \\
\hline & Market price of rice & yen/kg & 116.500 \\
\hline & Imports from China & $1,000 \mathrm{t}$ & $1,364.000$ \\
\hline & Tariff rate & $\%$ & 186.424 \\
\hline & $\begin{array}{l}\text { Required compensation to Korea } \\
\text { (f) }-(\mathrm{g})\end{array}$ & billion yen & 101.300 \\
\hline & Direct payment etc.(f) & billion yen & 204.700 \\
\hline & Tariff revenue (g) & billion yen & 103.500 \\
\hline & Net financial burden on Korea & billion yen & 124.200 \\
\hline \multirow{8}{*}{ China } & Supply & $1,000 t$ & $177,869.000$ \\
\hline & Demand & $1,000 t$ & $175,250.000$ \\
\hline & Market price of rice & yen/kg & 37.800 \\
\hline & Total exports & $1,000 t$ & $2,619.000$ \\
\hline & Exports to Japan & $1,000 t$ & $1,255.000$ \\
\hline & Exports to Korea & $1,000 t$ & $1,364.000$ \\
\hline & Required compensation to China & billion yen & 0.000 \\
\hline & Net financial burden on China & billion yen & 47.900 \\
\hline
\end{tabular}


FTA would widen gaps between rich and poor.

One of the key factors in promoting the East Asian FTA is an "equitable distribution of wealth." In this regard, Japan-Thailand FTA is one of the advanced achievements. It was agreed on the ground of a good balance between cooperation and liberalization; i.e., Thailand was flexible on Japan's sensitive products, while Japan ensured Thailand the cooperation for income improvement of Thai farmers.

Experiences in the EU integration might also give us a hint on how to solve this problem. For example, Greece and Southern Italy's agriculture is much less productive than the UK and Germany, but it is still surviving due partly to subsidies for handicapped farmers by the CAP (Common Agricultural Policy). This suggests the feasibility of the East Asian CAP.

The uneven distribution of FTA benefits can be redistributed across borders through a fund collected in proportion to the GDP level of each country just like the EU budget. As a part of this fund system, it is necessary to establish the East Asian CAP.

Suzuki (2005) analyzed the feasibility of the East Asian CAP in the case of rice among Japan, Korea and China as follows. The fund is contributed by three countries at a rate proportional to their shares of GDP (approximately, Japan: Korea: China =70:22:8). Japan abandons rice supply control. The compensation target prices are set at 200 yen/kg for Japan and 150 yen/kg for Korea. Farm gate rice prices of Korea and Japan are supplemented over the respective compensation target prices with direct payments from the fund. Under these conditions, when the ceiling of Japan's financial burden is 400 billion yen, Japan's rice tariff rate should be $186 \%$. As shown in Table 11, when Japan reduces rice tariff at $186 \%$ and offers contribution of 400 billion yen to the fund, Japan will suffer relatively small negative effects on self-sufficiency rate of rice and environmental load, while burdens of Korea and China won't be so large and China will gain from increases in exports.

\section{CONCLUSIONS}

The main findings of this study and suggestions for successfully promoting the East Asian FTA in the future can be summarized as follows.

(1) Since the current WTO rules have several unfair aspects favorable to exporting countries with large-scale farms like the U.S. and Australia, it would be impossible for Asian small-scale farming to survive under the rules. The rules are focusing on economic efficiency without considering equitable distribution of wealth and external economies such as national security and environmental concerns. Furthermore, it is said that a total ban on export subsidies by the end of 2013 was agreed, but the pledge is very unlikely to be fulfilled because many "hidden" export subsidies are left out of this agreement. (2) Therefore, East Asian countries should reaffirm the need for creating their unique FTA. We should aim to establish common values on diversity-oriented and environmental-conscious development and growth of Asia based on their diversified farming and several common characteristics such as small-scale rice farming. However, our analysis showed that the East Asian FTA could endanger existence of Japan and Korea's rice farming because of huge gaps in agricultural prices and costs between Japan/Korea and other East Asian countries. Also, free trade tends to benefit large farm owners, major food-processing firms and exporters, but it might bring poor majority further poverty in many cases. In addition, there would be just a slight difference in environmental impacts between the East Asian FTA and global trade liberalization under the WTO.

(3) Therefore, we need a measure to adjust the current agricultural gaps and eliminate rural poverty of the East Asia. In this regard, Japan-Thailand FTA is one of the advanced achievements. It was agreed on the ground of a good balance between cooperation and liberalization. Another feasible measure is establishing the East Asian CAP with a fund collected in proportion to the GDP level of each partner country just like the EU budget. Using the funds, the uneven distribution of FTA benefits can be redistributed across borders.

We do not have time to lose by fighting over leadership for the East Asian FTA. Especially, Japan and China should recognize importance of mutual cooperation. We should no longer be preoccupied with abstract arguments. It is time to discuss detailed substance based on a practical blueprint. For example, as we showed how much rice tariff reduction will be possible for Japan in Table 11, Japan should offer a concrete proposal comprehensively considering the following factors:

a) (Narrowly-defined) economic welfare,

b) Self-sufficiency rate of food for maintaining national security,

c) Indicators of environmental load such as food miles and virtual water,

d) Nitrogen balance, as the indicators of health risk as well as environmental load,

e) Equitable distribution of wealth, and

f) Budgetary constraints of each member country.

There are too many proposals on the rage of member countries to be included in the East Asian FTA. The U.S. is strongly against the East Asian FTA only by Asian countries. It is unfair because the U.S. is enhancing the NAFTA and then approaching to Asian markets. Asian countries should have a right to form a FTA only by Asian countries at first. So, possible East Asian FTA member countries should be the ten ASEAN countries + 3 (Japan, Korea, and China) at the first stage. Then, it could be gradually expanded. Including too many countries, e.g., Australia, New Zealand, or APEC countries, at the first step will make it difficult to discuss substance in detail.

\section{REFERENCES}

Hokazono, S. 2006 Policy Mix of Rice Tariff Reduction and Direct Payments. graduation thesis, Kyushu University (in Japanese)

JETRO 2003 WTO/FTA Column 018, (http://www.jetro.go. $\mathrm{jp} / \mathrm{biz/world/international/column/pdf/018.pdf),} \mathrm{JETRO}$ 
Kaiser, H. M., and N. Suzuki (ed.) 2006 New Empirical Industrial Organization and the Food System. Peter Lang Publishing Inc., New York

Krugman, P. 1991 Is Bilateralism Bad? In "International Trade and Trade Policy", ed. by E. Helpman and A. Razin, MIT Press, Cambridge, MA, pp. 9-23

Maeda, K., and H. Kano 2005 Estimating validity of the East Asia emergency rice reserve program using a spatial equilibrium model. In "Research Report on Modeling and simulation for the international emergency grain reserve program assessment", ed. by N. Suzuki, Kaken Research Report, Japan Society for the Promotion of Science (in Japanese)

OECD 1999 Post-Uruguay Round Tariff Regimes, OECD Publishing, Paris

Oki, T., M. Sato, A. Kawamura, M. Miyake, S. Kanae, and K. Musiake 2003 Virtual water trade to Japan and in the world. In "Virtual Water Trade: Proceedings of the International Expert Meeting on Virtual Water Trade", ed. by A. Y. Hoekstra, (http://www.waterfootprint.org/index.php? page $=$
files/Publications), UNESCO-IHE, Delft, pp. 221-235

Shindo, J., K. Okamoto, and H. Kawashima 2003 A model-based estimation of nitrogen flow in the food production-supply system and its environmental effects in East Asia. Ecological Modeling, 169: 197-212

Suzuki, N. 2005 FTA and Agri-Food Trade; Theory and Method of Impact Analysis. Tsukuba-shobo, Tokyo (in Japanese).

Suzuki 2006 Feasibility analysis of the East Asian common agricultural policy. Noringyo-Mondai Kenkyu, 161: 37-44 (in Japanese)

Suzuki, N., J. Kinoshita, T. Fujii, and H. M. Kaiser 2005 Measuring the Export Subsidy Equivalents (ESEs) through Price Discrimination Generated by Exporting State Trading Enterprises. Journal of the Faculty of Agriculture Kyushu University, 50(2): 743-751

Zushi N. 2004 Estimating Domestic Milk Premiums Using a Contingent Consumer Valuation Survey. graduation thesis, Kyushu University (in Japanese) 